\title{
Ruth Mackay (2019) Life in a Time of Pestilence. The Great Castilian Plague of 1596-1601. University Printing House, Cambridge, United Kingdom. P. 276. ISBN: 978-1-108-49820-3. doi: $10.1017 / 9781108632720$.
}

Родионова Ю.В. выпускник кафедры Истории Церкви Исторического факультета МГУ им. М.В.Ломоносова, ORCID: 0000-0002-6378-6317, e-mail: cardio2008@yandex.ru

Для цитирования: Родионова Ю.В. Ruth Mackay (2019) Life in a Time of Pestilence. The Great Castilian Plague of 1596-1601. University Printing House, Cambridge, United Kingdom. P. 276. ISBN: 978-1-108-49820-3. doi:10.1017/9781108632720. Обзор книги. Российский журнал истории Церкви. 2020;1(3):110-123. doi:10.15829/2686-973X-2020-3-38

\section{Ruth Mackay (2019) Life in a Time of Pestilence. The Great Castilian Plague of 1596-1601. University Printing House, Cambridge, United Kingdom. P. 276. ISBN: 978-1-108-49820-3. doi: $10.1017 / 9781108632720$.}

Yulia V. Rodionova, graduate of the Department of Church History of the Historical faculty of M. V. Lomonosov Moscow State University, ORCID: 0000-0002-6378-6317, e-mail: cardio2008@yandex.ru

For citation: Rodionova YV. Ruth Mackay (2019) Life in a Time of Pestilence. The Great Castilian Plague of 1596-1601. University Printing House, Cambridge, United Kingdom. P. 276. ISBN: 978-1-108-49820-3. doi:101017/9781108632720. Review. Russian Journal of Church History. 2020;1(3):110-123. doi:10.15829/2686-973X-2020-3-38

Смертоносные эпидемии чумы неоднократно волнами прокатывались по территории Европы в Средневековье. В Испании XVI в. таких эпидемий наблюдалось несколько с периодичностью тридцать-тридцать пять лет. Последняя, начавшаяся в конце 1596 г., по оценкам исследователей, унесла с собой до 500 тыс. человек только в Кастилии, что составило десять процентов ее населения. Эта вспышка чумы хорошо задокументирована в воспоминаниях современников, научных трактатах, официальной переписке и документах муниципальных архивов. Автор монографии совершила целое путешествие и предприняла попытку взглянуть на эпидемию конца XVI в., рассмотрев ее с точки зрения событий, происходивших в обыденной жизни: как люди, облеченные властью, реагировали на сообщения о чуме, какие меры принимались, как это повлияло на торговлю и обычный уклад жизни, во что эти люди верили и на что надеялись. Рут Маккей предлагает своим читателям современный взгляд на понимание изменений в социальной и экономической жизни во время смертельной эпидемии. 
Необходимо сразу отметить не только структуру книги, но и ее концептуальное построение: автор, в отличие от других ${ }^{1}$, не пишет исторический обзор о состоянии политической власти и королевской династии до Филиппа III и в его время и не исследует чумную палочку, переписывая учебник. Книга разбита на семь больших глав: дворец, дорога, городская стена, рынок, улица, ратуша и постель больного. В каждой из них рассматриваются вопросы, связанные с повседневной жизнью, которая разворачивалась на глазах обывателя и вовлекала в череду событий каждого, кто оказался в это время в районах Кастилии, уже пораженных чумой или еще не затронутых болезнью.

В первой части книги - “Дворец”, речь идет о повседневной жизни королевского двора во время правления королей Испании Филиппа II и его сына - Филиппа III, законах и идеологии власти, столкнувшейся с эпидемией. “Дорога” - о путешественниках, препятствиях, трудностях, передаче новостей и распространении товаров. Затем любой путешественник подходит к “Городской стене”, через ворота попадает на “Рынок”, где происходит обмен товарами, далее он идет по "Городским улицам", преображенным запахами и видами чумы, заходит в “Ратушу”, где правители города обсуждают насущные дела по спасению жителей, и наконец, достигает "Постели больного”, где, возможно, и заканчивает свой путь.

Алгоритм рассмотрения вопросов микроистории, предложенный автором, удобен для читателя книги, но вызывает некоторые трудности при аналитическом рассмотрении - темы, затронутые в разных частях, порой очень близки, и если разбирать информацию по такому плану, то невозможно избежать повторов. Поэтому вопросы, связанные, например, с церковными властями и медицинской оценкой событий, я буду компоновать, хотя у автора книги они поднимаются понемногу в разных частях.

Книга начинается с карт, чтобы читателю было понятно, о каких областях далее пойдет речь: общей карты с указанием только городов Сантандер, Бильбао, Бургос, Вальядолид, Мадрид, Толедо, Валенсия, Севилья - для общего представления, карты северного побережья иберийского полуострова и карты окрестностей Бургоса - городов Сантандер, Бильбао и Сан-Себастьян, поскольку в них появились первые заболевшие. Также автор перечисляет архивы, материалы которых были использованы для написания монографии.

Кастилия в то время представляла лесистую местность, пересеченную обширными степями и редкими реками. Главные города, через которые проходили сухопутные и водные пути, были окружены более мелкими городками и частными хозяйствами (vecinos), которые административно входили к юрисдикцию какого-либо муниципалитета. Интерес автора сосредоточен не на сравнительном исследовании Кастилии и окружающих ее регионов, а на изучении микроистории - социальных и политических связей - во время эпидемии чумы.

\footnotetext{
1 Приведу в пример книгу William Rosen “Justinian's Flea: Plague, Empire and the Birth of Europe”, в которой большая часть посвящена историческому обзору времени правления императора Юстиниана и его предшественников, а остальная часть - современной микробиологии.
} 
Главное последствие начала эпидемии - это социальная разобщенность, распад внутрисемейных отношений, о чем имеется множество свидетельств. Затем - страх, который охватывает людей, столкнувшихся с болезнью и смертью близких и соседей. Растерянность, заставляющая только молиться о спасении. Все эти признаки, о которых сохранилась память предков, постоянно наблюдаются в обществе, пусть и уже неоднократно пережившем эпидемии, но каждая является своим собственным уникальным случаем, поэтому рассмотрим исследование Рут Маккей еще и с тех позиций, которые могли бы привнести определенное знание о временах чумных эпидемий, о которых осталось не так много свидетельств.

Согласно общей легенде, Великая Кастильская чума 1596-1602 гг. прибыла на судне “Родамундо” из Дюнкерка или Кале в Сантандер вместе с грузом тканей в ноябре 1596 г. Сначала эпидемия протекала почти незаметно, и многие, в том числе врачи того времени, не верили, что смертоносная болезнь в самом деле - бубонная чума. В испанских документах о ней чаще говорится как о secas (раны на месте пораженных тканей), чем о peste (с традиционными бубонами в местах расположения лимфатических узлов), однако в современные исследования погребений этой эпохи подтвердили, что все-таки это была эпидемия бубонной чумы, вызванная чумной палочкой.

Вначале королевская власть в Кастилии, которую представлял в то время Франсиско Гомес де Сандоваль-и-Рохас, в будущем - могущественный герцог Лерма, прислушиваясь к мнению королевского медика Луиса Меркадо, всячески отрицала, что болезнь, распространяющаяся с севера в сторону Мадрида, именно чума. Тому было множество причин - пустая казна, оставшаяся после Филиппа II, англо-испанская война, война в Нидерландах, неурожаи, голод, потребность восстановления величия испанского флота. Безусловно, слухи о начале эпидемии чумы спокойнее было считать преувеличенными, особенно потому, что в это время новые корабли строились на верфях рядом с портом Сантандера. Проведение многочисленных религиозных процессий и молитв, оставшееся в памяти предков весьма успешным в прошлые годы, казалось властям наиболее эффективным инструментом для успокоения людей. Уже в начале 1597 г. первые заболевшие были замечены в Мадриде, в это же время болезнь распространялась вдоль побережья и в августе того же года охватила СанСебастьян, однако в течение еще двух лет врачи на собраниях ${ }^{2}$ продолжали утверждать, что эта болезнь - secas, а не чума, поскольку люди умирали в считанные дни от сильной лихорадки, но без бубонов ${ }^{3}$.

Однако нельзя упрекнуть власти, что они никак не отреагировали на слухи: королевский дворец в Мадриде обрабатывали уксусом, а потом двор вообще переехал в Вальядолид, на север страны были отправлены посланцы

\footnotetext{
2 Доктор Луис Меркадо и его коллеги предложили свое экспертное мнение Совету Кастилии, собранному по предложению короля, 13 апреля 1599 г. о том, что болезнь, охватившая все королевство, не является чумой.

${ }^{3}$ Клинические формы бубонной чумы: "первично-септическая" (озноб, бред, кожные петехии, рвота с кровью и продолжительность жизни от нескольких часов до трёх суток), “бубонная” (с присоединением бубонов иммунная реакция лимфатических узлов, ближайших к месту укуса блохи), “легочная" форма (вторичная), когда появляется кровохарканье, "амбулаторная чума" - бубоны появляются и затем исчезают.
} 
с целью расследовать происходящее. На месте они уже столкнулись с болезнью и только наблюдали карантинные меры, предпринятые местными властями, и их последствия - приостановку торговли, изоляцию, массовое бегство населения.

Помимо слухов о надвигающейся болезни, королевская власть начала получать многочисленные петиции из городов с просьбами о снижении налогов в королевскую казну, однако, судя по свидетельствам, приведенным автором книги, рассмотрение их искусственно затягивалось, а затем и вовсе последовали отказы, поскольку королевская власть в то время считала, что города должны сами нести все бремя, наложенное эпидемией. Здесь еще нужно напомнить о таком факте, как постоянное противостояние муниципалитетов Кастилии и королевской власти по поводу влияния и важности местных законов и обычаев; поэтому война, строительство кораблей, власть и торговля значительно больше занимали короля, чем внутригородские проблемы. Единственное, что было предпринято королевской властью - это введение запрета на проведение ярмарок, который, по свидетельству посланника, приведенному автором книги, легко игнорировали на местах, пока городской совет сам не принимал такого решения.

Еще один интересный факт: жители Кастилии часто приписывали происхождение чумы в своем городе одной конкретной женщине. В стране басков ответственность была возложена на весь женский пол, несмотря на то, что женщины активно помогали при госпиталях и умирали там же. После эпидемии в Сан-Себастьяне и Бильбао из городов были высланы все одинокие женщины, не родившиеся там. В заявлениях муниципалитетов некоторых городов говорилось, что болезнь началась, потому что они разрешили въезжать иногородним и женщинам незнатного происхождения (или женщинам свободных нравов - mujercillas, mugercillas), которые покупали себе вещи у бедняков или носили их “за двоих". Еще одним обвинением было, что именно женщины покупали задешево простыни, которые были привезены из зараженных мест, и поэтому никто в их семьях не выжил. Автором приводятся слова священника из Сан-Себастьяна, что гибель четырехсот женщин “была подарком Господа городу, поскольку они еще более заразны, чем сама чума”.

Рут Маккей цитирует еще одно интересное свидетельство безымянного посланника Совета Кастилии в город Алькала-де-Энарес (окрестности Мадрида) в конце июня 1599 г. о карантинных мерах, принимаемых центральной властью. Он отделил здоровых от больных и переместил всех, у кого обнаруживались secas и бубоны, за пределы города. В устроенной больнице было три коридора, в самом большом находились 450 больных. Все помещения окуривались ароматическими травами, а персонал старался работать раздельно и получал хорошую пищу. Мертвых хоронили в глубокой яме и засыпали известью. Город был разделен на восемь округов, каждый из которых возглавлял видный горожанин, в каждом были врач, священнослужители и стражники, которые в случае необходимости доставляли пациентов в больницу. Белье сжигали в большой печи, устроенной на расстоянии километра от города. Когда автор послания приехал, каждый день умирало двадцать пять или тридцать человек, а теперь их 
число сократилось до четырех или пяти. К концу сентября (через три месяца) в Алкале уже не было ни одного человека, который был бы опасно болен. Городские улицы тщательно убирали. Бедные получали одежду, пищу и лекарства за счет города. Также в числе предпринятых за время карантина мер автор послания пишет об организации охраны городских стен, изгнании чужаков и массовом истреблении кошек и собак.

Королевская власть призывала на время прекратить судебные тяжбы, однако автор книги считает, что не везде местные власти подчинились этим запретам. Наоборот, карантинные меры, изъятие частных домов под больницы, нарушения запретов властей на передвижение - все эти действия вели к новым судебным делам и разбирательствам.

Города, находившиеся в очаге эпидемии и на его границах, постоянно обменивались специальными “списками зараженных городов”. Эти списки вывешивались у главных ворот или на площадях, зачитывались глашатаями. Дело в том, что еще одной важной карантинной мерой стала перепись жителей города и его vecinos. Часто всех чужаков (не-горожан), в том числе - студентов, незамужних женщин и нищих, изгоняли ${ }^{4}$. А внутрь города впускали только жителей, выходивших за периметр стен по своим делам, или прибывших из городов, не входящих в “списки”. Все передвижения через ворота тщательно фиксировались в специальных реестрах, а новоприбывших своих же горожан допрашивали. Если город стоял на реке, то возводились хитроумные приспособления, препятствовавшие проходу вдоль берега, а лодки тщательно проверяли. Возможно, впервые во время этой эпидемии чумы упоминаются специальные нотариально заверенные документы, удостоверяющие личность горожанина.

Дороги в Кастилии в обычные годы никогда не пустовали, все активно передвигались: товары на мулах и телегах, письма в сумах специальных почтальонов, ремесленники в поисках работы, студенты, нищие, паломники. В условиях закрытия многих городов на карантин больший урон был нанесен торговле, когда погонщики мулов (те, кто занимался перевозкой грузов) и торговцы оказались не у дел, но с севера на юг двинулись толпы спасающихся от чумы и изгнанных из городов, зачастую принося с собой инфекцию в области, свободные от болезни.

Однако нарушение карантинных мер - даже принятие родственников из других городов или тайное размещение кого-либо на ночлег - каралось очень сурово. Автор приводит примеры, когда впущенных в город чужаков помещали в тюрьму, а тех, кто их принял, наказывали ста ударами плетей, большими штрафами или высылкой из города. В сознании средневековых людей прочно утверждалась мысль о принадлежности к городу (общине), которой нельзя вредить даже ради личных желаний. Наоборот, горожане обязывались помогать “своим” бедным и малоимущим. Обмен товарами с ближайшей округой часто производился через скиты (ermitas) - там оставляли необходимые вещи, деньги или письма, их тщательно дезинфицировали, а оттуда в назначенный день их забирала другая сторона.

${ }^{4}$ Бургос еще в январе 1579 г., узнав о чуме в Сантандере, составил списки и выслал из города пятнадцать мужчин и шестьдесят две женщины. Не указывается, состояли ли они в браке, имели ли детей. 
Таким образом, две формы изоляции - изгнание и карантин - в какойто степени были противоположными механизмами, но обе использовались для борьбы с инфекцией. Одно было внешним изгнанием, другое - внутренним. Трактирщикам и владельцам гостиниц было запрещено принимать посторонних гостей.

Эти меры зачастую, по мнению автора книги, запаздывали, а количество заболевших скрывалось, потому что остановка торговых связей и перемещений грозила большими убытками.

Городские стены едва ли представляли собой совершенно неприступные преграды. Часто они были сплошными по всему периметру и неизбежно разрушались, так как были сделаны из известняка. Внутри стен люди устраивали дома и лавки. Наружу вели многочисленные “калитки" (portillos), чтобы было удобнее ходить к полям. Рвы, если они вообще были, заполнялись мусором. Многие города не имели стен вообще или только в некоторых районах, что облегчало доступ внутрь. Кастилия давно не вела войн на своей земле, поэтому городские стены становились эфемерным административным или торговым барьером. Ради принятия карантинных мер городам за свой счет пришлось восстанавливать стены, замуровывать калитки и обеспечивать охрану. Для входа в город оставались только одни ворота, за ключами от них тщательно следили: автор книги отмечает некоторые случаи, когда ключи от ворот или тайных калиток были предметом торговли нечистых на руку людей.

Стражники (часто это люди, входящие в городской совет, или аристократы) стояли на воротах или делали объезды вокруг стен верхом. Они пропускали vecinos (фермеров или пастухов, живущих в округе), naturales (жителей, которые родились в городе), moradores (жителей, имеющих дома в городе), но охраняли ворота от forasteros (пришлых, иногородних), romeros (пилигримов, паломников), бедняков и других лиц, прибывших из городов “чумного списка".

Ворота отпирались в пять часов утра и закрывались в десять часов вечера. У посторонних путников требовали нотариально заверенные показания из того города, из которого они прибыли, или специальную бумагу с печатями городов, через которые они шли. Любой, кто пытался войти с яйцами, птицей или рыбой, должен был принести нотариально заверенное свидетельство о том, где были куплены продукты; людей, у которых не было свидетельства нотариуса о том, что они прожили двадцать дней или дольше в городе, из которого они приехали, не пропускали.

Чтобы противодействовать контрабанде, понадобился королевский указ: Р. Маккей приводит историю одного торговца купца, который тайно торговал тканями. Его товар был конфискован, а сам виновный приговорен к 200 ударам плетью и шести годам на галерах.

Фермеры и крестьяне оказались в особенно затруднительном положении, когда объявляли карантин. Город и деревня не были отдельными мирами: многие крестьяне занимались в межсезонье каким-нибудь ремеслом, люди в деревнях в течение нескольких поколений могли работать на 
шерстяной и льняной мануфактуре, почти все горожане ухаживали за урожаем вне городских стен, будь то владельцы или рабочие. Правила нарушались довольно часто.

Автор отмечает и тот факт, что именно во время эпидемии чумы в конце XVI в. ее распространение стали связывать с одеждой и работой с льном и сырой шерстью. Мытье шерсти было запрещено в некоторых городах.

Введение карантинных мер останавливало торговлю и передвижение товаров, цены росли, массовая гибель людей сказывалась на посеве и уборке урожая, возникала не только нехватка рабочих рук, но и голод все эти процессы автор книги пытается проследить в главе “Рынок". Автор рассматривает несколько вопросов. Во-первых, различие между богатыми, которые питались хорошо, и бедными, которые голодали. Последние чаще становились жертвами чумы. Во-вторых, вопрос запасов продовольствия перед объявлением карантина, действительно, волновал городские власти, и они организовывали специальные "рейды" по изъятию излишков продовольствия. Также из мест, входящих в списки “зараженных чумой” было запрещено привозить или покупать там какие-либо продукты и товары. Известия о чуме в том или ином городе приходили "со слухами”, поэтому довольно часто использовалось в торговых спекуляциях. Зерно, ставшее в этих условиях особенно ценным продуктом, становилось порой еще дороже даже не из-за спекуляций, а из-за того, что теперь его везли издалека. Причем автор отмечает, что в компетенцию королевской власти входило право разрешать распределять зерно среди бедных, минуя обычные правила торговли, или предоставлять займы под залог муниципальной собственности на покупку зерна.

Рыба была самым распространенным продуктом питания, привозимым с севера, и она присутствовала в рационе питания у большинства людей. Эпидемия чумы, охватившая побережье Бискайского залива, остановила поставку рыбы во внутренние регионы.

В дни, на которые не приходились очередные церковные праздники, на столе кастильского горожанина могли быть: баранина, цыплята, куриное мясо, каплуны, кислый виноград, апельсины, лимоны, кислые яблоки и другие продукты, которые легко перевариваются. Однако, на основании проведенного анализа архивной документации, автор книги полагает, что торговля не останавливалась, несмотря на все проводимые властями меры - бюрократические, физические и финансовые.

Внутри городских стен обычная жизнь очень изменилась - о ней говорится в главе под названием “Улица". Большинство ремесленников, чьи мастерские обычно располагались в глубине дома или на задворках, но которые продавали свои товары перед домом, исчезли. Не было никаких отчетов о смертности, но и не требовалось никаких списков, чтобы люди знали, что их соседи уехали, умерли или были отправлены в больницу. Часто чиновники или члены городских советов вместе с семьями просто бежали из города зараженного города в соседние. Так, городской совет Бильбао переехал в Португалете (а его глава (corregidor), возможно, пере- 
ехал в Дуранго), Португалете, по-видимому, - в Баракальдо, Ларедо в Ампуэро, вице-король Наварры перебрался из Памплоны в Олите. Города пытались задержать своих представителей власти путем наложения огромных штрафов ${ }^{5}$ : от 30 тыс. до 50 тыс. мараведи, если сбежавшие вновь вернутся в город.

Священство, по данным автора, поступало схожим образом. Во время вспышки чумы в Галисии в августе 1569 г. кафедральный капитул Сантьягоде-Компостела проголосовал за то, чтобы позволить почетным каноникам покинуть город, остались всего девять человек, трое из которых, согласно современному источнику, были кардиналами. К февралю 1570 г. все вернулись обратно. Отъезд представителей высшего клира мог привести к спорам с городом, который часто полагался на священников и другие религиозные власти в плане заботы о больных и умирающих. В Санто-Домингоде-ла-Кальсада, в современной Ла-Риохе, городской совет яростно и бесплодно боролся, чтобы помешать церковному капитулу и епископу уехать в течение чумного лета 1599 г. В Бургосе кафедральный капитул в апреле 1599 г. попросил городской совет разрешить служителям церкви, желающим уехать, сделать это; некоторые уже пытались бежать, но бдительные стражники остановили их у городских ворот. Гражданские власти на местах, возможно, все еще пытались скрыть факт того, что чума уже близко, но священнослужители были настойчивы - они не верили врачам, заверявшим, что болезнь - не чума, и знали, что она очень заразная. Городской совет Бургоса разрешил священникам уехать, но сам епископ остался и, по слухам, был образцом милосердия и самопожертвования, неустанно и мужественно посещая больных и тратя на них свои деньги. Совет в Бильбао также столкнулся с нежеланием священников оставаться в городе: в сентябре 1599 г. поступили жалобы на то, что приходские священники не проводили последние обряды (миропомазание и Святое Причащение (Viaticum)), поэтому люди умирали “без духовного утешения", “порождая тем самым ненужные сплетни и слухи”.

Столкновения между государством и церковью во время эпидемий имели тенденцию сосредоточиваться на трех вопросах: карантин, реквизиция монастырского и другого церковного имущества в пользу больниц и запрет на большие собрания. К перечисленному автор книги добавляет еще один пункт - отказ духовенства платить специальные налоги, чтобы компенсировать расходы на чуму. Закрытый на карантин город препятствовал священникам ухаживать за больными и не позволял здоровым посещать богослужения.

Если люди убегали, то они явно куда-то направлялись, но это место не могло быть домом друзей или членов семьи в общинах, защищающих себя от чумы (поскольку чужаков, как было выше упомянуто, выгоняли). И, хотя

\footnotetext{
${ }^{5}$ К сожалению, автором книги не было проведено сравнительное исследование стоимости одного "мараведи" и товаров в этот исторический период. В комментариях можно найти данные о денежной системе того периода: 1 дукат (3,5 г золота) стоил 11 реалов (1 реал = 3, 35 г серебра) и 375 мараведи (медная монета). 1 реал = 34 мараведи. Имеется одно упоминание о стоимости кувшина вина в 2 мараведи. Посланник, перевозящий письма из города в город, получал 400-500 мараведи в день или по таксе 187 мараведи за каждые 10 лиг (55 км).
} 
Евангелие призывало к человеколюбию и гостеприимству ${ }^{6}$, в условиях карантина и страха перед смертельной болезнью эти заповеди забывались. Документальные свидетельства фиксируют случаи, за то, что путешественников пускали в дом, город мог наказать штрафом, плетьми или изгнанием, даже если гости не несли с собой угрозы заражения. Владельцев гостиниц наказывали схожим образом.

Восприятие болезни простыми людьми было не однозначным, судя по фразам, имеющимся в источниках, хотя автор книги на этом важном аспекте практически не концентрирует внимания. Болезнь считалась проявлением “воли Господа" - редко указывается в документах, что в “наказание за грехи”: “поскольку болезнь чумы из-за грехов наших распространилась по всему побережью”; “то ли оттого, что прибыло созвездие, то ли оттого, что зараза усилилась, то ли оттого, что Господь решил так поступить с толпой, многие люди стали чувствовать себя плохо, и от этой болезни, столь явной, наш город был разрушен, и мало-помалу он начал гореть”; “как будто болезнь была духом, который различал вещи, который естественным образом брал на себя бремя поиска всех уголков всех домов, ожидая осторожных и раня любопытных, удаляя одних, скрываясь от других, оставляя брошенных и хватая самых осторожных, захватывая самых сильных и игнорируя самых слабых, исцеляя больных и убивая здоровых...”.

Во время эпидемии общая атмосфера в городе была удручающей: оставались больные, бедняки, сироты, несколько лавочников, ремесленников и торговцев, иногда - врачи, чиновники и священники, не бежавшие из чувства долга, мужчины, отправившие жен и детей в безопасные места, жители, тайно укрывавшие родственников. Они ждали и молились. Часто умирающие не могли попрощаться со своими родными и близкими, так как все бежали от чумы. Тишину нарушал только голос городского глашатая, который был привычной частью повседневной жизни в городах Испании.

Обычно глашатаи (pregones) ходили по улицам города, останавливались на площадях, по несколько раз на дню громко выкрикивали правила гильдии, максимальные цены на хлеб и другие продукты питания, соглашения о налогообложении фермерских хозяйств, наказания за различные правонарушения, новые законы против роскоши, дни предстоящих аутодафе и праздников, имена тех, кого городской совет назначил исполнять то или иное общественное дело, открытие торгов и ярмарок. В годы чумы они читали и перечитывали списки чумных городов, предупреждали трактирщиков, чтобы те не впускали путников без надлежащего удостоверения личности, приказывали людям сообщать о своих умерших и сдавать белье, угрожали наказаниями за разрушение стен и призывали бедных собраться в определенном месте для распределения и изгнания после раздачи некоторой милостыни. Их, естественно, сопровождали нотариусы, не только для того, чтобы удостовериться в правильности зачитанного, но и для того, чтобы иметь свидетеля, того, что тот или иной акт в действительности имел место (был озвучен).

\footnotetext{
${ }^{6}$ Мк. 12:31 (Рут Маккей отсылает к Лк. 10:27): “возлюби ближнего твоего, как самого себя”, Мф. 25:35: “ибо алкал Я, и вы дали Мне есть; жаждал, и вы напоили Меня; был странником, и вы приняли Меня".
} 
По оценке автора, до эпидемии в одном доме могло проживать достаточно много людей: на одну семью, в среднем, трое детей, пожилые родители, слуги; если хозяин дома - ремесленник, то еще один-два подмастерья. В Мадриде в 1597 г. в каждом доме было по семь человек, хотя могло быть и больше, дома там строились меньше по размеру, чем в других городах и деревнях. Те, кто остался в покинутых городах, вероятно, были одиноки и имели меньше дел, чем в обычное время; у ремесленников почти не было заказов, если горожане работали в поле, то постоянно проходили проверки. Все таверны были закрыты. Приготовление пищи, уборка, стирка, уход за животными, возможно, заготовка пищи - единственная деятельность, которая оставалась горожанам. Детская смертность, судя по замечаниям автора, была очень высока: в одних городах умерли практически все дети в возрасте до десяти лет, а в Бургосе, наоборот, стало очень много детей-сирот.

Если кто-то из домочадцев был болен, то, конечно, обязанностью остальных было сообщить о случившемся властям, однако, судя по документальным свидетельствам, многие люди скрывали и прятали больных (и мертвых, которые умерли без последнего обряда), что вызывало постоянные проверки и обходы домов с нотариусом и со стражей. Если чужаков обнаруживали спрятанными в домах, то их выгоняли вместе с остальными членами дома - или вообще из города, или помещали во временный госпиталь, а дом закрывали. Автор обращает внимание читателя на эту меру: закрывали не дом и живших в нем, а именно пустой дом. После снятия карантина дома горожан сначала специально обрабатывали, прежде чем в них вновь заселяться. Хотя и изоляция больных в доме тоже применялась, но не повсеместно - по мнению автора, при отсутствии мест в больнице или упорном нежелании заболевших покидать дом; в Мадриде были специальные карантинные дома на определенных улицах, зарезервированные для больных.

Сжигание одежды и постельного белья умерших было важной составляющей городских противочумных мер. Как только города узнавали о приближении чумы, они немедленно выставляли стражу, отделяли больных от здоровых, закрывали дома с больными и сжигали одежду. Костры устраивали за пределами города, а внутри городские улицы окуривались ароматическими травами, которые, как считалось, были полезны для здоровья.

Оружие, деньги, драгоценности, посуду, бумаги, неиспользованное постельное белье стирали и хорошую мебель протирали уксусом. Из домов заболевших также изымали воротники, манжеты, рубашки и носовые платки. Нужно отметить, что после эпидемии власти могли компенсировать утраченное, если выжившие обращались в суд и заявляли, что действиями властей им был нанесен значительный ущерб.

Город нанимал специальных рабочих, которые собирали одежду умерших и сжигали ее. Больных перевозили на тележках, тачках, носилках и доставляли в больницы за городскими стенами. В Валенсии проблема высокой оплаты труда могильщиков и нежелания многих приближаться к больным чумой была решена за счет рабов и заключенных, которым предложили смягчить наказание. Общие могилы устраивались либо за стенами 
города, либо рядом с больницей - еще одна необходимая карантинная мера, которая вызывала недовольство и попытки спрятать тела умерших, а потом перезахоронить их на церковных кладбищах. Церковные власти не поддерживали такое стремление не только по санитарным соображениям, но и по причине нехватки мест для такого большого количества умерших. “Тайные” похороны при попустительстве местного священника практиковались, например, в Бильбао.

Коррехидор обычно имел и судебные полномочия, поэтому назначал наказания. В общих чертах, суровость наказаний преследовала две цели: не только наказать преступника, но и удержать других от совершения преступления. Судя по документам, пишет автор, во время этой эпидемии чумы было на удивление мало уголовных преступлений, зато множество нарушений карантина. Никаких социальных потрясений тоже не было. Публичное порицание (verguenza pública) в виде порки плетьми на площади обычно назначалось за сопротивление властям, бродяжничество, побег из тюрьмы, лжесвидетельство, двоеженство, проституцию и воровство, но применялось редко.

Рут Маккей, исследуя общественную религиозную жизнь, пришла к выводу, что большие религиозные собрания на открытом воздухе или процессии были редкостью в условиях чумы и карантинных мер. В этом плане оставшееся в городах духовенство и власти проявляли солидарность. Большую популярность набирали личные votos - обеты, посвященные определенному святому: они не требовали процессий, хотя заражение внутри церковного здания и распространение болезни таким образом было наиболее вероятным. Обеты приносились святым Фирмину и Себастьяну, но наибольшее почитание приобрел культ еще в то время еще неканонизированного святого Роха ${ }^{7}$ как защитника от чумы.

Театральные представления, juegos de toros y cañas и прочие были запрещены королевской властью, в качестве противочумной меры, но бывало, что на местах считали иначе: “шествия, костры и корриды - поднимали людям настроение”.

Географическим и политическим центром любого города была ратуша (ayuntamiento, здание городского совета), обычно расположенная рядом с городским собором или напротив него. Там устанавливались цены, устраивались шествия, осуществлялось финансирование, централизовалась связь, происходили конфликты между правящими фракциями, простолюдинами и дворянами. Поведение отдельных городских лидеров отражало, конечно, их индивидуальный характер, но также и то, насколько они понимали или верили в принципы хорошего правления, которые были частью каждого закона, петиции или устава. В контексте чумы ложь в политических целях могла рассматриваться как своего рода дополнительное укрепление, защищающее интересы города. Однако христианские авторитеты совершенно ясно давали понять, что лжи не может быть оправдания. Поведение назначенных королевской властью чиновников, по мнению автора книги, заслуживает рассмотрения в контексте современных дискуссий

${ }^{7}$ Рох изг. Монпелье. Канонизирован в 1629 г. 
о том, что они должны и чего не должны делать во время эпидемии или случившейся катастрофы. Так, первый открытый совет (concejo abierto) в Бильбао, на который были созваны горожане и vecinos, состоялся только в октябре 1598 г. в самый разгар чумы. До этого Бильбао всячески отрицал эпидемию. Было принято решение о переписи населения и о том, что богатые обязаны давать деньги на противочумные меры и помогать бедным под угрозой ареста и заключения в тюрьму. Все сбежавшие также обязаны были внести свой вклад и не могли вернуться, не заплатив.

Пока пересматривались налоги, укреплялись городские стены, контрабандой ввозились и вывозились товары, отменялись ярмарки, доставлялись припасы, сжигалась одежда, издавались приказы и проводились собрания - люди болели и умирали.

За те пять лет, что длилась эпидемия, погибло около полумиллиона человек. Некоторые города потеряли пятую или более часть своего населения. В Мадриде чума началась в 1597 г., но в конце 1599 г. все еще встречались случаи заболевания. Согласно донесению мадридского коррехидора в начале августа 1599 г. еженедельно умирало около 100 человек. А в июне этого же года коррехидор Вальядолида (соседнего крупного города) продолжал уверять короля Филиппа III, что болезнь на самом деле - не чума. Возможно, такое нежелание принимать очевидное было еще связано и с денежным вопросом - на строительство больниц нужны были средства.

Новые больницы представляли собой отдельные здания для больных и выздоравливающих, пациенты перемещались из первых во вторые, если болезнь отступала, а медицинский персонал размещался в зданиях за пределами городских стен. Церковь и религиозные ордена по всей Кастилии часто выступали за то, чтобы держать городские ворота открытыми в определенное время, чтобы позволить своим членам посещать отдаленные деревни и лазареты, однако, судя по документальным источникам, отдельные напуганные священники и монахи иногда просто исчезали или отказывались подходить к больным.

Проблема городов заключалась еще и в их обеспечении врачами: в Бургосе в 1561 г. было семь дипломированных врачей, пять хирургов, пятнадцать цирюльников и шесть аптекарей. В Толедо в 1599 г. на население в 9 тыс. домохозяйств приходилось пять врачей. В Вальядолиде имелась медицинская школа, в конце июня 1599 г. городской совет решил запросить у медицинского факультета врача и хирурга, желающих помочь в больнице Сан Лазаро, однако через неделю постановил, что никакие врачи, хирурги или выпускники не могут покинуть город, но если они уйдут, то будут оштрафованы на 200 дукатов. В обычных обстоятельствах врачи получали от города плату в 40-50 тыс. мараведи в год, во время чумы ставки возросли - 1500 мараведи в день или 1200 мараведи за одного больного.

Проблема заключалась и в самой квалификации врачей, столкнувшихся с эпидемией: многие из них, по оставленным свидетельствам, считали бубоны доброкачественными, смертность низкой, а новую болезнь не очень опасной. Они часто высмеивали своих же коллег. Король Филипп III опирался на мнение личного врача Луиса Меркадо, что это "не чума" и даже заплатил 2 тыс. дукатов за издание его книги, где лучшим способом 
борьбы с болезнью объявлялось молиться, обрабатывать вещи и помещения уксусом и делать добрые дела. Однако нужно отметить, что Меркадо, отчасти, правильно указывал на воздух как носитель и переносчик болезни . Далее он называл, несомненно, полезным вскрытие ран и использование слабительных. За эти годы в Испании были написаны десятки подобных сочинений о чуме ${ }^{9}$. Большинство трактатов появились на латыни в традиции научных дебатов и конкуренции мнений, но без практической пользы.

Автор монографии, сосредоточиваясь на карантинных мерах, мало пишет о клинических признаках и еще меньше - о способах лечения, которые применялись в то время. Конечно, интересно было бы прочитать какие-либо свидетельства очевидцев о том, что происходило внутри больничных стен как была организована помощь, сортировка больных, что использовалось при лечении. Автор приводит только одно “живое” свидетельство о лечении зараженного чумой, у которого не было бубонов: кровопусканием, сначала из правой руки, потом левой, а когда и эта мера не помогла - из обеих рук.

Относительно симптомов автор книги пишет обобщенно: “симптомы, как правило, были таковы: у людей появлялись горячие, болезненные бубоны в паху или подмышечной впадине, которые могли развиваться несколько дней, а затем разрываться, выделяя гной и/или кровь. На конечностях развилась гангрена. Другие повреждения, вызванные кровоизлияниями, появлялись по всему телу, и они могли почернеть, набухнуть и лопнуть, а затем высохнуть; это были так называемые secas и/или карбункулы. Больные страдали высокой температурой и умирали через три-семь дней от момента проявления первых признаков". Однако из единственного приведенного в одной из глав книги свидетельства, мы можем понять, почему врачи не желали принимать болезнь за чуму. Дебют заболевания был острым: у больного поднялась высокая температура, глаза налились кровью, он бредил и жаловался на боль в ноге или паху. На второй день на коже больного появились небольшие опухоли белого цвета (secas), на третий день человек умер. На следующий день был собран консилиум врачей, который с уверенностью заявил, что это не чума, а “довольно распространённое и легкое заболевание”. Еще через два дня болезнью было охвачены все домовладения на улице, где скончался первый больной, а дальше болезнь распространилась по всему городу ${ }^{10}$.

Считалось, что можно заразиться от ткани, от другого человека, от воздуха (или смещения небесных сфер) или от их сочетания, и что люди могли бы не заболеть или могли бы выжить, если бы они были здоровее и лучше питались с самого начала. Одни говорили, что это мор, другие - что нет, третьи думали, что это совершенно новая болезнь или, может быть, комбинация известных болезней.

\footnotetext{
${ }^{8}$ Современные исследователи обнаружили, что этот трактат был большей частью переписан с трактата 1565 г. доктора Хуана Томаса Порселла (Dr. Juan Tomás Porcel).

${ }^{9}$ Семьдесят три в XVII в., начиная с 1590 г.

${ }^{10}$ Свидетельство указывает на трехдневный период болезни, видимое отсутствие бубонов и инкубационный период примерно в пять дней до проявления первых признаков заболевания. Больной становится заразным до проявления первых признаков болезни. Также врачами не отмечается почернение конечностей типичный признак чумы XIV в.
} 
В своей книге Рут Маккей несколькими абзацами все же пытается указать на полемику среди историков и ученых-специалистов по чуме. Несоответствие сезонных сроков, скорости распространения болезни, симптомов, воздействия таких мер общественного здравоохранения, как карантин, а также отсутствие известных носителей и переносчиков привели критиков к утверждению, что Вторая пандемия, включающая Кастильскую чуму, не была бубонной чумой и не была вызвана возбудителем Yersinia pestis. Однако последние достижения в вирусологии и археологии подтверждают, что жертвы болели именно чумой, вызванной чумной палочкой в классическом варианте. Бактерия может оставаться живой в спящей форме в почве в течение нескольких месяцев или лет. Возможно, шерсть и ткань в самом деле представляли опасность, так как внутри них зараженные блохи могли перемещаться с места на место.

В конце книги автор приводит некоторые статистические данные о жертвах чумы относительно июня-июля 1599 г. Так, в июне в приходах и монастырях Вальядолида было похоронено 455 человек, за июль в приходах и больницах умерли 2181 человек, за первую неделю августа - 647 человек. В пригороде Севильи за первую неделю августа умерли 54 человека, в самом городе в июне умерли в двух больницах 2298 больных, выздоровели 1672 , в первую неделю июля - поступили 458 человек, умерли 333, выздоровели - 384, таким образом, смертность доходила до 45-47\%. Дети в этой страшной статистике не учитывались, известно, что большинство умирало.

Монография Рут Маккей “Жизнь во время чумы. Великая Кастильская чума 1596-1601" является интересным исследованием, основанным на документальном материале, которое может быть полезно специалистамисторикам, изучающим не только этот период или историю Испании в целом, но и для проведения сравнительного анализа социокультурной и экономической повседневной жизни людей в городах в условиях эпидемии. 